\title{
Article \\ Evaluation of Hawaiian Heritage Sweet Potato (Ipomoea batatas (L.) Lam.) Breeding Lines
}

\author{
Todd Anderson ${ }^{1, *}$, Theodore Radovich ${ }^{2}$, Jon-Paul Bingham ${ }^{3} \odot$, Nicolas Sinclair ${ }^{3}$, Giselle Bryant ${ }^{2}$ and \\ Michael Benjamin Kantar ${ }^{2}$ (1) \\ 1 Department of Horticulture, Oregon State University, Corvallis, OR 97331, USA \\ 2 Department of Tropical Plant and Soil Science, The University of Hawaii at Mānoa, Honolulu, HI 96822, USA; \\ theodore@hawaii.edu (T.R.); gbryant@hawaii.edu (G.B.); mbkantar@hawaii.edu (M.B.K.) \\ 3 Department of Molecular Biosciences and Bioengineering, The University of Hawaii at Manoa, \\ 3050 Maile Way, Honolulu, HI 96822, USA; jbingham@hawaii.edu (J.-P.B.); nsinclai@hawaii.edu (N.S.) \\ * Correspondence: andetodd@Oregonstate.edu
}

check for updates

Citation: Anderson, T.; Radovich, T.; Bingham, J.-P.; Sinclair, N.; Bryant, G.; Kantar, M.B. Evaluation of Hawaiian Heritage Sweet Potato (Ipomoea batatas (L.) Lam.) Breeding Lines. Agronomy 2021, 11, 1545. https:/ / doi.org/10.3390/agronomy11081545

Academic Editor: Carlos Iglesias

Received: 8 June 2021

Accepted: 29 July 2021

Published: 31 July 2021

Publisher's Note: MDPI stays neutral with regard to jurisdictional claims in published maps and institutional affiliations.

Copyright: (c) 2021 by the authors. Licensee MDPI, Basel, Switzerland. This article is an open access article distributed under the terms and conditions of the Creative Commons Attribution (CC BY) license (https:/ / creativecommons.org/licenses/by/ $4.0 /)$.

\begin{abstract}
Producing 'Hawaiian Heritage' cultivars can raise the market value of locally grown sweet potatoes and increase small farmer earnings in Hawaii. Twelve sweet potato breeding lines (Ipomea batatas L.), derived from the Hawaiian maternal parent 'Mohihi', together with four check varieties, were trialed under organic management conditions across three environments (site-year combinations) in Oahu, Hawaii (Waimānalo-2018, Waimānalo-2019 and Poamoho-2019). Trials were harvested five months after planting, consistent with local commercial production standards. There were significant differences in fresh harvest yield, post-curing yield, shape, and quality between environments and cultivars. The 'Hawaiian Heritage' lines HM 26 and HM 34 outperformed the commercial standard, demonstrating the potential use of traditional Hawaiian germplasm in modern breeding programs. Additionally, 'Hawaiian Heritage' lines (e.g., HM 32 and HM 17) with unique traits favored by the local community may be suitable breeding materials for niche markets.
\end{abstract}

Keywords: participatory plant breeding; Waimānalo Pono Research Hui; heirloom

\section{Introduction}

Sweet potato is a globally important crop that is of particular interest to Hawaii due to its long history of cultivation. The sweet potato has been cultivated by the Hawaiian people since antiquity [1,2]. Sweet potato is a staple crop in traditional Hawaiian agriculture and has helped sustain the Hawaiian population for centuries [3]. Historically, in Hawaii, sweet potato was gown on well-drained sandy soils, they were occasionally grown on clay soils due to the popularity of the crop, but this typically reduced production [4]. Native Hawaiians and other small-holders practicing organic agriculture have an increased interest in fresh and value-added markets [5].

During the 20th century, sweet potato was a valuable export crop for Hawaii [6], but despite its historical importance, production and sales have declined for decades [7]. In addition to a general poor return on the fresh market sweet potato for both local and export markets, labor costs and the specialized machinery required for harvest are often cost-prohibitive for small growers, potentially contributing to the market's decline [6]. In response, large operations have shifted to producing value-added goods due to the higher returns. However, infrastructure requirements to convert a crop into a value-added product (e.g., chips, fries, or beer) are again cost-prohibitive for small operations [5]. The impact of these financial barriers is reflected in Hawaii's declining farm gate value for sweet potatoes. During peak production, approximately 445 hectares were in cultivation and generated $\$ 7.3$ million, compared to just $\$ 1.8$ million and 196 hectares recorded in $2016[8,9]$. 
The cultural significance and vulnerable status of traditional Hawaiian sweet potatoes, much of which was lost in the 20th century, has motivated interest to develop new cultivars using locally adapted germplasm. There is considerable genetic diversity in traditional Oceanic sweet potatoes and substantial consumer interest across the region [10]. In Tonga, lines bred using a polycross block of Polynesian germplasm perform well in the local agroecosystems [11]. Although traditional Pacific cultivars often lack the competitive yields of commercial lines, they may be essential in developing future climate-resistant crops [12]. The price premium entitled to crops with traditional Hawaiian lineage and the increased consumer demand for locally produced goods may offset any potential yield deficits [13].

Breeding cultivars for organic production systems are using different approaches to increasing market value and improving earnings for small growers [14]. The selection pressures exerted under conventional and organic systems significantly vary, often constraining a cultivar's access to the respective system for which it was developed [14]. Growers can receive premiums ranging from $9-100 \%$ for vegetables and value-added goods produced organically, increasing their return on investments [15]. While sweet potatoes are grown across all of Hawaii's microclimates, commercial production has historically taken place in drier regions like Molokai [6]. However, the recent influx of commercial operations in the high-rainfall areas on the Big Island of Hawaii requires that breeding lines be selected for multiple environments.

Hawaii has an extensive history in modern breeding and sweet potato selection [16]. Previous work in cultivar development, production management, and nutritional research have primarily focused on sweet potato germplasm descending from Asia, parts of the mainland United States, and others with untraceable lineages [17]. Although some Hawaii landraces have previously been used in studies [18], the lack of widespread use places their future at risk as extant collections die off, are abandoned due to botanic garden closures, and the loss of personal collections. Despite these limitations, traditional Hawaiian cultivars maintain their status as a distinct population [19].

Integrating farmer and community input into a breeding program can ensure that new cultivars are adopted within a region [20]. Community collaborations focus on incorporating local needs more effectively, particularly by defining the breeding objectives and prioritizing the markets that are essential to the community. Integrating the needs identified by growers and indigenous groups allows for effective implementation, especially in underserved regions [21]. In Hawaii, the publics' participation is inspired by sweet potatoes' cultural value $[19,22]$ and supported through the working partnerships between State institutions and community organizations [23].

Hawaiian heritage cultivars comparable in quality and yield to the current commercial standard 'Okinawan' could improve the economic viability of sweet potato production for small and organic farmers in Hawaii. Therefore, this research aims to identify high-value cultivars with 'Hawaiian Heritage' lineage suitable for fresh-market and value-added production in Hawaii. Specifically, the objectives were to compare newly developed breeding lines derived from 'Hawaiian Heritage' with commercial standards and historic heirloom varieties.

\section{Materials and Methods}

\subsection{Plant Material}

In 2016, a randomized complete block design to continue a multi-year evaluation of several "Hawaiian Heritage" and other varieties at the Poamoho Research station on O'ahu was used to serve as a polycross block. The cultivars that served as potential pollen parents included: Hua Moa', 'Mohihi' from Waimea Gardens, 'Ele' ele', 'Papa'a Kowali', 'Lanai', 'Purple Kahānu', 'Ogasawara', 'Piko', 'Kahau Purple', 'Rapoza', 'Yama', 'MeleMele', 'Hui 17', 'Nancy Hall', 'H'Hale Tuahine', 'Lanai', 'Kala', 'Uala Kea', and 'Ho'olehua'. The seed was collected from 'Mohihi' (Lyon arboretum). In 2017, $\mathrm{F}_{1}$ seedlings were evaluated for root characteristics during a preliminary trial at the Waimānalo Research Station. From the initial 
evaluations, 12 superior $F_{1}$ lines were selected (Figure 1 ), and four check cultivars were sourced: (i) 'Okinawan', the standard commercial cultivar grown in the state, (ii) 'Lanikeha', a traditional Hawaiian variety prevalent among homesteaders on Molokai, (iii) 'Kahānu Purple', a popular variety used for traditional agricultural systems research on the Big Island, and (iv) 'Mohihi', the maternal parent sourced from Lyon Arboretum.

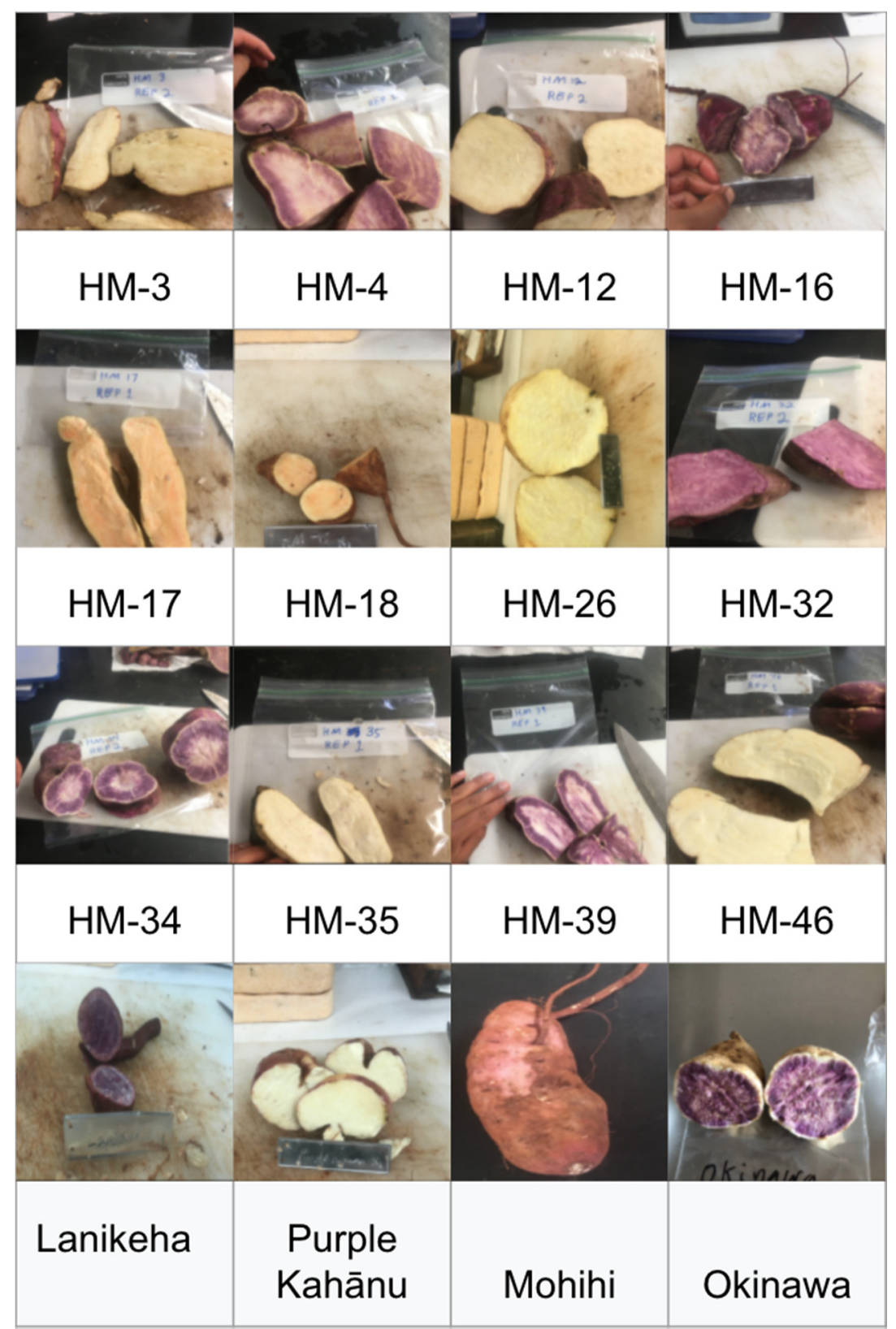

Figure 1. 'Hawaiian Heritage' breeding lines and check cultivars evaluated during this experiment. Okinawan is the commercial standard in Hawai' $\mathrm{i}$, while Mohihi from Lyon arboretum is the maternal parent, Purple Kahānu and Lanikeha are traditional Hawaiian varieties.

\subsection{Field Trials}

Field trials during 2018-2019 were conducted across two sites which represented three distinct year-location combinations for a total of three environments. Each site was selected to represent the principal areas of commercial sweet potato production in Hawaii. The Poamoho Research station $\left(21^{\circ} 33^{\prime} 42^{\prime \prime} \mathrm{N}, 158^{\circ} 4^{\prime} 19^{\prime \prime} \mathrm{W}\right)$ was chosen as the 'preferred environment' because of its low to moderate rainfall and well-drained soil (Oxisol, Wahiawa 
series). The Waimanalo Research Station $\left(21^{\circ} 20^{\prime} 5^{\prime \prime} \mathrm{N}, 157^{\circ} 43^{\prime} 16^{\prime \prime} \mathrm{W}\right)$ was selected to represent a 'less suitable environment' due to its high rainfall and heavy clay soil (Mollisol, Waialua series). In Waimānalo-2018, the trial was conducted as a randomized complete block design, with 12 treatments and three replications; in Waimānalo-2019 and Poamoho-2019, the trial consisted of 16 treatments and four replications, trials in 2019 and 2018 shared 12 treatments. The planting dates were October 2018 in Waimānalo-2018 and May 2019 in Waimānalo-2019 and Poamoho-2019. In Waimānalo-2018, blocks consisted of two 10-meterlong mounded beds. In Waimānalo-2019, each block contained two 16-meter-long beds. In Poamoho-2019, each block consisted of one 32-meter-length. Each row within blocks was 1.4 meters long, with 1.5 meters between each row. Plants were managed using standard organic practices and followed the University of Hawaii College of Tropical Agriculture and Human Resources extension guidelines [6], with some modifications to accommodate equipment limitations (e.g., manual cultivation) [6]. Organic fertilizer (Sustane 4-6-4) was incorporated into each bed through the field, and 1.22-meter woven plastic mats were placed between rows for weed control. Harvests for the first plantings took place in March and October of 2019. Sweet potatoes were cured in a chamber constructed from tarps and sealed with clamps to maintain a temperature of $32{ }^{\circ} \mathrm{C}$ and $90 \%$ humidity [6] for ten days.

\subsection{Phenotyping}

Twelve phenotypic measurements were collected: (1) root number produced, (2) forecasted yield in metric tonnes per hectare, estimated as the fresh yield of unsorted roots at harvest, (3) root shape determined using length by width measurements., (4) average root weight, (5) skin color, (6) flesh color, (7) proportion lost to weevil damage, (8) percent lost from rotting during curing, (9) percent that sprouted during curing, (10) uncured sucrose content, (11) cured sucrose content, (12) and marketable yield after curing, calculated as the remaining roots without signs of sprouting, weevil damage, or rotting.

For the sucrose analysis, tissue samples (20 grams) were taken from individual roots of each breeding line. The sample tissue was extracted from the center of the root, freeze-dried, powdered, and mixed in a solution of distilled water and ethanol $(50 / 50 \mathrm{v} / \mathrm{v})$. The solution was centrifuged at 10,000 rpm for $15 \mathrm{~min}$, and the resulting supernatant was isolated, decanted, and re-centrifuged. This process was repeated four times to ensure the removal of all solid materials. The resulting solution was processed using high-performance liquid chromatography (HPLC), incorporating a Waters 2965 isocratic running pump system interfaced with a Waters 996 Photodiode Array Detector. Soluble sucrose concentrations were determined by comparing the peak area integration to known commercial sucrose standards (Fisher Scientific; (Supelco Analytical 47267 Monosaccharides kit). Peak area integration was estimated with Waters Millenium Software (V.4.00) and resolved using a Luna Omega $3 \mu$ SUGAR $100 \mathrm{~A}^{\circ}$ LC column $(250 \times 4.6 \mathrm{~mm})$ and filtered degassed solvent of Acetonitrile/ $\mathrm{H}_{2} \mathrm{O}(80 / 20 \mathrm{v} / \mathrm{v})$.

\subsection{Statistical Analysis}

All trial data were analyzed as an augmented design to account for missing data between environments. A mixed model, using replication within a year as the random effects and breeding line as the fixed effects, was analyzed with the R packages "lme4" [24] and "smartest" [25] and least-square means and contrasts between genotypes were calculated using the R package "emmeans" [26].

\section{Results}

A separate analysis of each environment (year-location combination) revealed extensive variation among the 'Hawaiian Heritage' breeding lines (Table 1). In the Waimānalo2018 trial, HM 26 was the only 'Hawaiian Heritage' breeding line whose yield exceeded the commercial check 'Okinawan' (Figure 1; Table 1). Additionally, the three lines, HM 26, HM 35, and HM 46) outperformed the Hawaiian check 'Lanikeha' No breeding line was significantly different from the maternal parent 'Mohihi'. Similarly, in Waimānalo-2019, 
HM 26 outperformed the commercial check 'Okinawan', and HM 26, HM 46, and HM 34 had higher yields than 'Lanikeha,' yet none of the lines were different from the maternal parent 'Mohihi'. In Poamoho-2019, HM 26 consistently out-yielded the commercial check 'Okinawan,' while the breeding lines HM 12, HM 16, HM 34, and HM 35 yielded more than 'Lanikeha'. Consistent with previous trials, none of the lines were statistically different from the maternal parent 'Mohihi' in Poamoho-2019.

Table 1. Least Square Means for Yield and Shape.

\begin{tabular}{|c|c|c|c|c|c|c|c|c|}
\hline \multirow{2}{*}{$\begin{array}{l}\text { Breeding } \\
\text { Line }\end{array}$} & \multicolumn{3}{|c|}{ Fresh Yield Metric Tonnes per Hectare } & \multicolumn{3}{|c|}{$\begin{array}{c}\text { Post-Curing Yield Metric Tonnes } \\
\text { per Hectare }\end{array}$} & \multicolumn{2}{|c|}{$\begin{array}{l}\text { Shape Width by } \\
\text { Length }\left(\mathrm{cm}^{2}\right)\end{array}$} \\
\hline & $\begin{array}{l}\text { Waimānalo } \\
2018\end{array}$ & $\begin{array}{l}\text { Waimānalo } \\
2019\end{array}$ & $\begin{array}{l}\text { Poamoho } \\
2019\end{array}$ & $\begin{array}{l}\text { Waimānalo } \\
2018\end{array}$ & $\begin{array}{l}\text { Waimānalo } \\
2019\end{array}$ & $\begin{array}{l}\text { Poamoho } \\
2019\end{array}$ & $\begin{array}{l}\text { Waimānalo } \\
2018\end{array}$ & $\begin{array}{c}\text { Poamoho } \\
2019\end{array}$ \\
\hline HM12 & $32.8^{+}$ & $9.66^{+}$ & $26.09^{+}$ & $28.77^{\dagger}$ & $9.07^{\dagger * \ddagger}$ & $26.11^{+}$ & 2.55 & 2.21 \\
\hline HM16 & $35.41^{\dagger}$ & $12.27^{\dagger}$ & $28.7^{\dagger}$ & $29.54^{\dagger}$ & $9.83 * \ddagger$ & $26.88^{\dagger}$ & 2.52 & 2.18 \\
\hline HM17 & 13.57 & 0 & 6.86 & 10.81 & $0 * \ddagger$ & 8.15 & 3.61 & 3.27 \\
\hline HM18 & 28.85 & 5.71 & 22.13 & 24.26 & $4.56 * \ddagger$ & 21.6 & 2.69 & 2.35 \\
\hline HM26 & $39.91 *+$ & $16.77 *+$ & $33.2 * t$ & $36.09 * t \ddagger$ & $16.39 * \ddagger$ & 33.43 *†‡ & 2.48 & 2.13 \\
\hline HM3 & 28.36 & 5.22 & 21.65 & 24.19 & $4.48 * \ddagger$ & 21.53 & 2.65 & 2.31 \\
\hline HM32 & 27.75 & 4.61 & 21.04 & 24.27 & $4.57 \ddagger$ & 21.61 & $3.88 \ddagger$ & 3.54 ** \\
\hline HM34 & $31.74^{\dagger}$ & $8.59^{+}$ & $25.02^{\dagger}$ & $27.55^{\dagger}$ & $7.85 \ddagger$ & $24.89^{\dagger}$ & 3.5 & 3.16 \\
\hline HM35 & $36.08^{+}$ & $12.94^{+}$ & 29.37 & $30.87^{+}$ & $11.16 \ddagger$ & $28.21^{+}$ & 2.21 & 1.87 \\
\hline HM39 & 26.32 & 3.18 & 19.61 & 22.99 & 3.29 & 20.33 & 3.29 & 2.95 \\
\hline HM4 & 21.78 & 0 & 15.07 & 18.51 & 0 & 15.85 & 2.91 & 2.57 \\
\hline HM46 & $31.03^{+}$ & $7.89^{+}$ & 24.32 & $25.89^{+}$ & 6.19 & $23.23^{+}$ & 2.26 & 1.92 \\
\hline Lanikeha & 15.53 & 0 & 8.82 & 11.78 & 0 & 9.12 & 3.64 & 3.3 \\
\hline Mohihi Ly & 28 & 4.86 & 21.29 & 23.82 & 4.12 & 21.16 & 2.69 & 2.35 \\
\hline Okinawa & 21.64 & 0 & 14.92 & 17.78 & 0 & 15.12 & 2.79 & 2.45 \\
\hline $\begin{array}{l}\text { Purple } \\
\text { Kahānu }\end{array}$ & 26.16 & 3.02 & 19.45 & 22.19 & 2.49 & 19.53 & 2.39 & 2.05 \\
\hline
\end{tabular}

${ }^{*}$ Different from Okinawan; ${ }^{\dagger}$ Different from Lanikeha; ${ }^{\ddagger}$ Different from Purple Kahānu; ${ }^{* *}$ Different from Mohihi.

The variation in post-curing yields between the checks and 'Hawaiian Heritage' lines was inconsistent across environments (Table 1). In Waimānalo-2018, HM 3 and HM 26 were higher yielding than the commercial check 'Okinawan.' The lines HM 12, HM 16, HM 26, HM 35, and HM 46 were different from the Hawaiian cultivar 'Lanikeha', and no line differed from the maternal parent 'Mohihi,' or the Hawaiian cultivar 'Purple Kahānu'. In Waimānalo-2019, the commercial check 'Okinawan' did not perform well with many lines out yielding the check (HM 12, HM 16, HM 17, HM 18, HM 26, HM 3). Lines HM12, HM 16, HM 17, HM 18, HM 26, HM 3, HM 32, HM34, and HM 35 were different from 'Purple Kahānu'. No lines from the Waimānalo-2019 were different from 'Mohihi' or 'Lanikeha'. For the Poamoho-2019 planting, Lines HM 12, HM 16, HM 26, HM 34, HM 35, and HM 46 were different from 'Lanikeha'. Line HM 26 was different from 'Okinawan' and 'Purple Kahānu' as well. No lines were different from the maternal parent 'Mohihi' in the Poamoho-2019 planting.

For shape (Table 1), in Waimānalo-2018, Line HM 32 showed variation from 'Purple Kahānu', with all other lines being the same as the commercial check 'Okinawan,' the Hawaiian cultivars 'Lanikeha,' the maternal parent, and Hawaiian cultivar 'Mohihi'. In Poamoho-2019, line HM 32 was again different from 'Mohihi' while no other line was differed. No Line was different from the commercial check 'Okinawan'. There were notable variations in skin and flesh color, representing the range of what is acceptable in local Hawaiian markets (e.g., purple). For the remaining phenotypes (proportion lost to weevil damage, percent that rotted during curing, percent that sprouted during curing, uncured sucrose content, and cured sucrose content), there were no significant differences between the commercial checks and the breeding lines. However, there was variability in sucrose content across the environments, with sweet potatoes grown during Poamoho-2019 typically having higher soluble sucrose contents (Figure 2). There were notable differences 
in field performance across each environment, specifically in Waimānalo-2019, where there was massive crop loss due to sweet potato weevil. Weevil loss, rotting during curing, and yield was highly correlated to the growing environment. The trial in Poamoho-2019 produced the highest quality harvest and experienced significantly less rotting and weevil loss than the other environments (Figure 2).

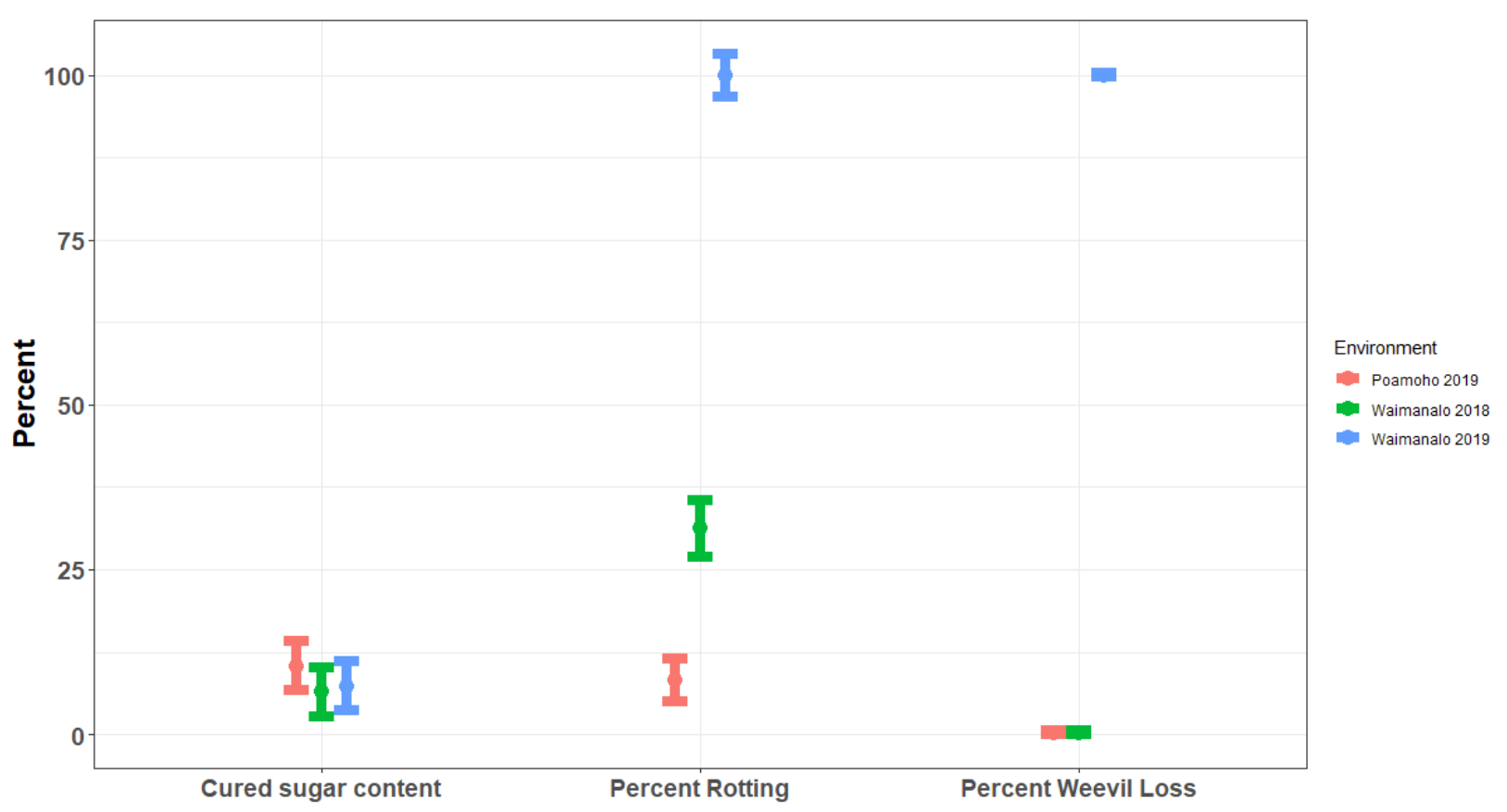

Figure 2. Comparison of performance at locations demonstrating the effect of planting location on phenotypic response. Each point represents the mean performance across all lines at a location, and error bars represent a $95 \%$ confidence interval around the mean line performance.

\section{Discussion}

This study assessed the potential of 'Hawaiian Heritage' breeding lines descended from traditional Hawaiian sweet potato cultivars. Yield metrics, root shape, damage susceptibility, color, and sucrose content were evaluated in twelve 'Hawaiian Heritage' breeding lines, one commercial standard, and three Hawaiian cultivars. There are two distinct markets for the 'Hawaiian Heritage' lines, the fresh and the processing market (e.g., brewing). There are five phenotypes essential to marketability in the fresh market; (1) metric tonnes per hectare, (2) shape, (3) yield post-curing, (4) total sucrose content, and (5) flesh color. Given these metrics, we employed a tiered decision tree to select Hawaiian heritage lines suitable for each market. (Figure 3). To allow for practical comparisons of cultivar performance under organic management, phenotypic differences within the decision tree are relative to both the commercial check 'Okinawan' and the traditional Hawaiian checks.

For processing cultivars (e.g., brewing), a cultivars fresh yield is the most critical trait. The sucrose content in sweet potatoes is of lesser importance to the brewing process because enzymatic digestion allows yeast to access energy from complex carbohydrates. Unlike fresh market sweet potatoes, the appearance of processing varieties is not subject to consumer opinions [27]. This research indicates that the 'Hawaiian Heritage' breeding line HM 26 was the top-performing line across all environments. HM 26 outperformed the commercial standard 'Okinawan' in fresh harvest weight, had the highest yields in each environment, and performed the same as the Hawaiian landrace 'Mohihi'. Other notable 'Hawaiian Heritage' lines were HM 26, HM 34, HM 46, HM 12, HM 16 and HM 35, which had greater yields than the traditional Hawaiian checks and had yields comparable to 'Okinawan' (Figure 3), meaning that these breeding lines have the potential for processing 
for uses by merit of their fresh yields. There is great interest in restoring historic phenotypes of broadly accessible and easily grown cultivars [22], in addition to having larger scale commercial types.

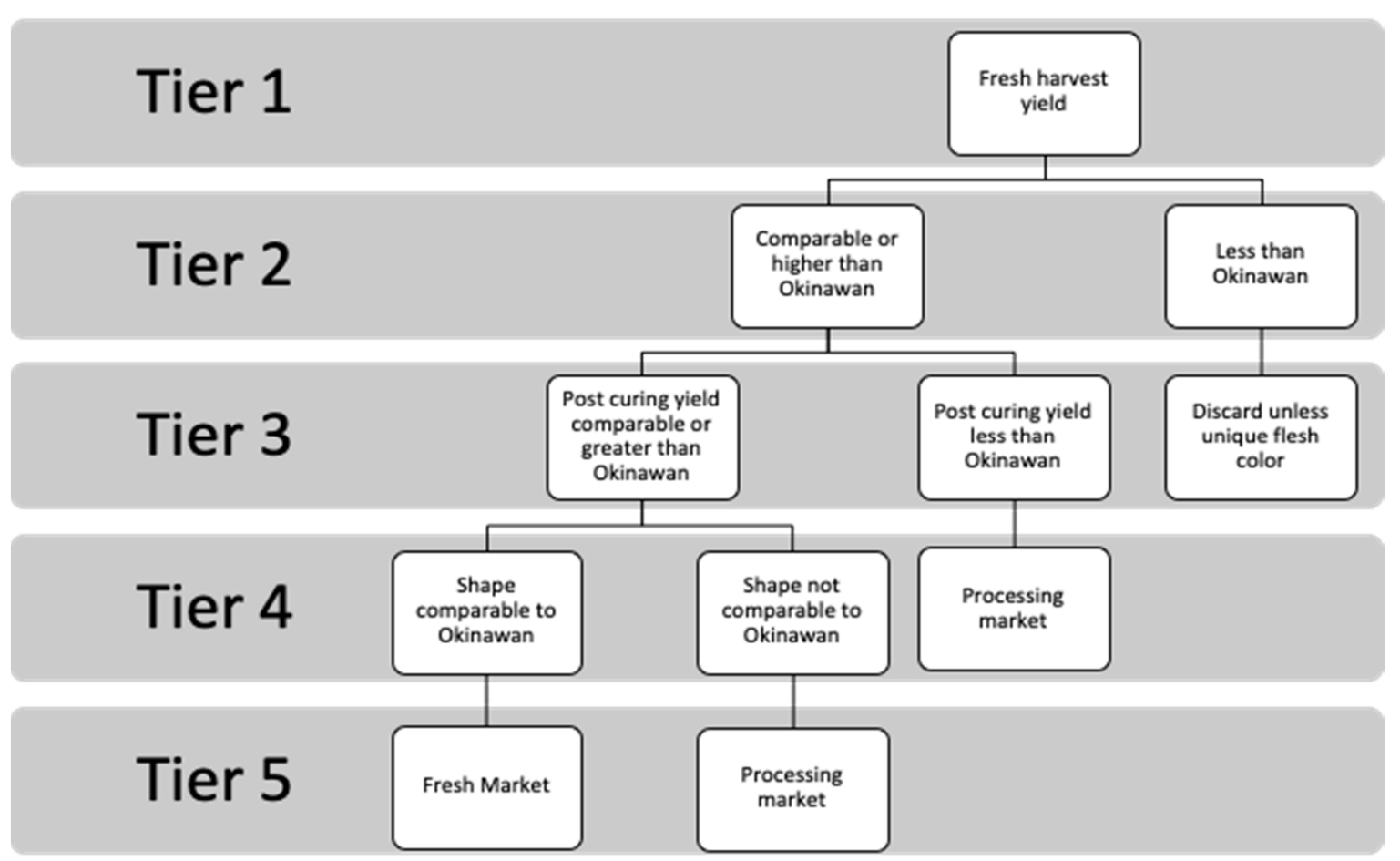

Figure 3. Selection roadmap for 'Hawaiian Heritage' cultivars. There are two primary selection targets. These are fresh market (or unprocessed) and for the processing market (brewing lines). Each selection trait is compared to the commercial standard Okinawan and Hawaiian cultivars at each tier. There are two entry points within this selection scheme at Tier 1; the first is before curing as this is not a common practice in Hawaii and the second is after curing, which is the industry standard. The fresh harvest yield is more relevant for processing and local consumption. In contrast, curing adjusted yield is more important for potential export, mainland, or if curing is more widely adopted locally. Selection occurs at each tier as a point of assessment for the breeding line.

The second stage of the selection process examines the potential of 'Hawaiian Heritage' breeding lines as fresh market cultivars. Among the 'Hawaiian Heritage' breeding lines, those with greater yields than the traditional Hawaiian varieties included HM 26, HM 34, HM 46, HM 12, HM 16 and HM 35. Elevated sucrose content in sweet potatoes is associated with improved taste and increases their market value [14]. The uncured sugar content is not a critical metric for producers in Hawaii because curing is not standard; however, if intended for alternative markets, a cultivar's cured sugar content will be essential to producers. There were no differences among the lines for the percentage of soluble sucrose in cured and uncured samples, so all breeding lines continued to the next selection factor. The variation in sucrose content identified during this study may have been due to increased solar radiation, which is characteristic of Poamoho. Higher solar radiation exposure for sweet potatoes has been correlated to increased sucrose content [27].

By choosing to cure the harvest in this study, marketable yield post-curing became a critical selection component. There was wide variation in the breeding lines in post-curing harvest yield; however, the best lines were HM 26, HM 3, and HM 34. This metric accounts for the yield lost during the curing process and are vital for fresh market export and storage This metric is related to factors other than just the curing process, including insect damage and shape [28]. Severe root damage from the sweet potato weevil (Cylas formicarius), a common sweet potato pest in Hawaii, prevented post-curing measurements from being taken during the Waimānalo-2018 trial. Although the vegetative growth appeared healthy throughout the trial, the pest damage to the roots resulted in widespread crop loss. This 
is a common issue for sweet potato producers in Hawaii, especially in areas with high rainfall, heavy clay soils, and a recent history of sweet potato cultivation [7].

The final tier in the selection process addresses the cultivars' shape and color. Classifying an 'advantageous' shape is slightly subjective and varies for each market. For this research, the objective was to identify 'Hawaiian Heritage' lines that have a comparable shape to the commercial standard 'Okinawan.' The shape must exhibit the desired blocky root form to meet the market demand and ensure existing processing machinery would not require modifications. The final important trait for fresh local markets is color, and in Hawaii, there is a preference for purple flesh. For this reason, although its yield was not superior to HM 26, the purple-fleshed line HM 34 may be a better candidate for local fresh market production. When all local selection requirements were taken into account, the best performing lines were HM 34 and HM 26. These two lines are excellent candidates for further study and may be suitable for the fresh and processing market. The unique appearance of other breeding lines, such as HM 32, may also be of interest for its uniform purple flesh and skin.

\section{Conclusions}

From this study, we identified commercially viable lines from the 'Hawaiian Heritage' breeding material. Lines HM 34 and HM 26 have the most potential for fresh market production, whereas HM 26 may be suitable for the fresh and processing markets. Consumer preference for white and purple flesh make HM 26 and HM 34, respectively, excellent candidates for fresh market production in Hawaii. Other breeding lines that did not meet the selection parameters here could be used in further breeding work for their unique coloration (HM 32, HM 39, HM17) or may have value to hobbyists and backyard growers. Future work should broaden the awareness of traditional Hawaiian sweet potato cultivars to promote local awareness and conservation.

Author Contributions: Conceptualization, T.A., G.B., T.R. and M.B.K.; methodology, T.A., J.-P.B., N.S., G.B.; formal analysis, T.A., J.-P.B., N.S., M.B.K., G.B.; investigation, T.A., G.B., N.S.; writingreview and editing, T.A., G.B., N.S., J.-P.B., T.R., M.B.K. All authors have read and agreed to the published version of the manuscript.

Funding: This research received no external funding.

Institutional Review Board Statement: Not applicable.

Informed Consent Statement: Not applicable.

Data Availability Statement: The data are available upon reasonable request from the authors.

Acknowledgments: We would like to thank the following: Jay Bost for assistance in assembling varieties from collections across Hawaii that were used in these trials, Tiare Silvasy and Sarah Moore for technical assistance with the production of seedlings, Staff at the Waimānalo and Poamoho Research Stations for plot maintenance, Aurora Kagawa-Viviani, and the Waimānalo Pono Research Hui for their guidance and advice. Finally, we would like to thank the many volunteers who helped with the harvest.

Conflicts of Interest: The authors declare no conflict of interest.

\section{References}

1. Ladefoged, T.N.; Graves, M.W.; Coil, J.H. The introduction of sweet potato in Polynesia: Early remains in Hawai'i. J. Polyn. Soc. 2005, 114, 359-373.

2. Hartshorn, A.S.; Chadwick, O.A.; Vitousek, P.M.; Kirch, P.V. Prehistoric agricultural depletion of soil nutrients in Hawai'i. Proc. Natl. Acad. Sci. USA 2006, 103, 11092-11097. [CrossRef] [PubMed]

3. Kurashima, N.; Fortini, L.; Ticktin, T. The potential of indigenous agricultural food production under climate change in Hawai'i. Nat. Sustain. 2019, 2, 191-199. [CrossRef]

4. Chung, H.L. Sweet Potato in Hawaii. Hawaii Agricultural Experiment Station, University of Hawaii. 1923. Available online: https:/ / www.ctahr.hawaii.edu/oc/freepubs/pdf/B-50.pdf (accessed on 10 July 2021). 
5. Krishnakumar, J.; Chan-Halbrendt, C.; Radovich, T.; Sullivan, P.; Love, K. Supply-demand integrated management model for effective farmer-buyer coordination: Case of the Hawaii avocado industry. J. Chain Netw. Sci. 2009, 9, 17-23. [CrossRef]

6. Valenzuela, H.; Fukuda, S.K.; Arakaki, A. Sweetpotato Production Guides for Hawai'i; HITAHR, College of Tropical Agriculture and Human Resources, University of Hawai'i: Honolulu, HI, USA, 1994.

7. Pulakkatu-thodi, I.; Motomura-Wages, S.; Miyasaka, S. Evaluation of insecticides for the management of rough sweet potato weevil, Blosyrus asellus (Coleoptera: Curculionidae) in Hawai'i island. Crop. Prot. 2018, 114, 223-227. [CrossRef]

8. Yamakawa, O. Development of sweet potato cultivars for new processing use in Japan. Trop. Agric. 1998, 75, $284-287$.

9. Hawai'i Department of Agriculture. 2018 Hawaii Vegetable and Melon Crops Report. 13 June 2018. Available online: https: // www.nass.usda.gov/Statistics_by_State/Hawaii/Publications/Vegetables/2017/201701vegrv.pdf (accessed on 10 July 2021).

10. Miyasaka, S.C.; Wall, M.; LaBonte, D.; Arakaki, A. Sweetpotato Cultivar Trials on Hawai 'i Island. HortTechnology $2019,1,1-9$.

11. Zhang, D.; Rossel, G.; Kriegner, A.; Hijmans, R. AFLP assessment of diversity in sweet potato from Latin America and the Pacific region: Its implications on the dispersal of the crop. Genet. Resour. Crop Evol. 2004, 51, 115-120. [CrossRef]

12. Wilson, J.E.; Pole, F.S.; Smit, N.E.J.M.; Taufatofua, P. Sweet Potato (Ipomea batatas) Breeding: Agro-Facts IRETA Publications. No_/89. 1989. Available online: https://www.ctahr.hawaii.edu/adap/Publications/Ireta_pubs/sweet_breeding.pdf (accessed on 10 July 2021).

13. Champagne, A.; Legendre, L.; Lebot, V. Chemotype profiling to guide breeders and explore traditional selection of tropical root crops in Vanuatu, South Pacific. J. Agric. Food Chem. 2009, 57, 10363-10370. [CrossRef]

14. Glover, D.; Stone, G.D. Heirloom rice in Ifugao: An 'anti-commodity' in the process of commodification. J. Peasant. Stud. 2018, 45, 776-804. [CrossRef]

15. Dos Santos, A.M.; Lima, J.S.; dos Santos, I.F.; Silva, E.F.; de Santana, F.A.; de Araujo, D.G.; dos Santos, L.O. Mineral and centesimal composition evaluation of conventional and organic cultivars sweet potato (Ipomoea batatas (L.) Lam) using chemometric tools. Food Chem. 2019, 273, 166-171. [CrossRef]

16. Dimitri, C.; Oberholtzer, L. Organic price premiums remain high. Amber Waves Econ. Food Farming Nat. Resour. Rural. Am. 2005, 3, 2-3.

17. Poole, C.F. Seedling Improvement in Sweet Potato/C.F. Poole. In Technical Bulletin. 1952. Hawaii Agricultural Experiment Station; No. 17; University of Hawaii Agricultural Experiment Station: Honolulu, HI, USA, 1952. Available online: https: / / agris.fao.org/agris-search/search.do?recordID=US201300687999 (accessed on 10 July 2021).

18. Huang, A.; Tanudjaja, L.; Lum, D. Content of alpha-, beta-carotene, and dietary fiber in 18 sweetpotato varieties grown in Hawaii. J. Food Compos. Anal. 1999, 12, 147-151. [CrossRef]

19. Winnicki, E.; Kagawa-Viviani, A.; Perez, K.; Radovich, T.; Kantar, M. Characterizing the Diversity of Hawai 'i Sweet Potatoes (Ipomoea batatas [L.] Lam.). Econ. Bot. 2021, 75, 1-15. [CrossRef]

20. Almekinders, C.J.M.; Elings, A. Collaboration of farmers and breeders: Participatory crop improvement in perspective. Euphytica 2001, 122, 425-438. [CrossRef]

21. Bänziger, M.; Cooper, M. Breeding for low input conditions and consequences for participatory plant breeding examples from tropical maize and wheat. Euphytica 2001, 122, 503-519. [CrossRef]

22. Kagawa-Viviani, A.; Levin, P.; Johnston, E.; Ooka, J.; Baker, J.; Kantar, M.; Lincoln, N.K. I Ke Ēwe 'Āina o Ke Kupuna: Hawaiian Ancestral Crops in Perspective. Sustainability 2018, 10, 4607. [CrossRef]

23. Chung-Do, J.J.; Ho-Lastimosa, I.; Keaulana, S.; Ho, K., Jr.; Hwang, P.W.; Radovich, T.; Albinio, L.; Rogerson, I.; Keli ‘iholokai, L.; Deitschman, K.; et al. Waimānalo pono research hui: A community-academic partnership to promote Native Hawaiian wellness through culturally grounded and community-driven research and programming. Am. J. Community Psychol. 2019, 64, 107-117. [CrossRef] [PubMed]

24. Bates, D.; Maechler, M.; Bolker, B.; Walker, S.; Christensen, R.H.B.; Singmann, H.; Dai, B.; Scheipl, F.; Grothendieck, G.; Green, P. Package 'lme4'. Version 2018, 1, 17.

25. Kuznetsova, A.; Brockhoff, P.B.; Christensen, R.H. lmerTest package: Tests in linear mixed-effects models. J. Stat. Softw. 2017, 82, 1-26. [CrossRef]

26. Lenth, R.; Lenth, M.R. Package 'lsmeans'. Am. Stat. 2018, 34, 216-221.

27. Agata, W.; Takeda, T. Studies on Matter Production in Sweet Potato Plants: 1. The Characteristics of Dry Matter and Yield Production under Field Conditions. J. Fat. Agric. Kyushu Univ. 1982, 27, 65-73.

28. Atuna, R.A.; Carey, E.E.; Low, J.W.; Amagloh, F.K. Wound healing and dry matter content of orange-fleshed sweet potato cultivars as influenced by curing methods. Open Agric. 2017, 2, 274-279. 